\title{
Revegetation at the Sullivan Mine: Research to Closure - A Case Study
}

John E. Przeczek PRYZM Environmental Ltd, Cranbrook, BC, Canada

Dave Ryder Teck Resources Limited, Kimberley, BC, Canada

\begin{abstract}
The Sullivan ore body was a world class iron-lead-zinc sulphide deposit that was discovered in 1892 near what became Kimberley, BC. The Sullivan mine operated from 1910 to 2001.

A research program to investigate the conversion of waste rock dumps and tailing ponds into productive forest and rangeland was initiated in 1972. Initial studies focused on revegetation treatments for waste rock and mill tailings. Studies demonstrated that complex covers with at least $30 \mathrm{~cm}$ of growth medium is required to grow a satisfactory grass dominated plant community and at least $60 \mathrm{~cm}$ is required where alfalfa is a desired component. The studies also indicated that a float rock capillary barrier in the complex cover reduced the movement of acids, salts and metals into the growth medium.
\end{abstract}

The reclamation plan prescribed the installation of native tree and shrub islands and corridors, extensive revegetation with agronomic grass and legume species and inclusions of small islands of native grasses. Native tree and shrub screening trials were used to determine which species would have adequate survival rates to contribute to the development of the wildlife habitat end use objectives. Treatments that created conditions that were free from competitive vegetation were tested to improve the probability of tree and shrub planting success.

Vegetation monitoring protocols were developed to ensure that initial revegetation efforts were successful and long term revegetation results would achieve end use objectives. Ongoing monitoring includes species composition, biomass productivity ( $\mathrm{kg} / \mathrm{ha}$ ), metals in soils and metal uptake in vegetation.

Revegetation strategies that include the incorporation of native grass and legume islands need to consider the invasive nature of agronomic species with appropriately sized (large) islands. In addition, native tree and shrub islands and corridors need to be large enough to create unique and purposeful wildlife habitats. The long term succession in agronomic plant communities will be assessed through a rationalized monitoring program. In the future, the plan is to incorporate the investigation of other ecological parameters including soil development, root development, soil flora and fauna, and use patterns by a range of wildlife species.

\section{Introduction}

The Sullivan ore body, located near what is now Kimberley, in southeastern BC (Figure 1), was discovered in 1892. The Consolidated Mining and Smelting Company of Canada Limited acquired the property in 1908 and mining operations began in 1910. After 91 years of operation, the Sullivan Mine closed on December $21^{\text {st }}, 2001$. The designated end land use objective for the mine is wildlife habitat. This has evolved into "creating diverse sustainable wildlife habitats that provide similar function as local native plant communities". Research programs that focused on converting waste rock dumps and tailing ponds to productive forest and rangeland were initiated in 1972.

Results from various research studies conducted from 1972 - 2000 directly influenced the development of the operational reclamation program at the Sullivan Mine. Complex covers consisting of a minimum of 60 $\mathrm{cm}$ of glacial till over a minimum of $50 \mathrm{~cm}$ of float rock were constructed over mill and resloped mine wastes to promote acceptable growth of grass and legume dominated plant communities.

Where native trees and shrubs were required to meet end land use objectives an additional $50 \mathrm{~cm}$ of glacial till was placed over the complex cover system to provide planting sites that were free of moisture competition from the seeded grass and legume plant communities. Six native tree and ten native shrub species were planted in combinations of linear features (corridors, 3x100 m) and patches (islands, 20x20 m). 
These plantings were initially designed to provide security cover and browsing opportunities for ungulates and nesting sites for passerine birds.

\section{Summary of research results}

Initial studies conducted from 1972 - 1978 showed that it would not be feasible to manipulate iron or siliceous tailings to create conditions that would accommodate adequate plant growth (Przeczek, 2004). In addition, although vegetation would establish on waste rock if it was adequately supplied with lime, maintenance fertilizer, and fines to support plant growth, it was clear that results would be variable and species diversity would be limited (Gardiner and Rusnell, 1980). Soil cover experiments were initiated between 1977 and 1994 to test various soil cover configurations over a variety of mill wastes (Table 1, Figure 1). The last research report was produced in 2000.

Table 1 Summary of the soil cover experiments conducted at the Sullivan Mine 1977 - 2000 (from Przeczek, 2004)

\begin{tabular}{|c|c|c|c|c|}
\hline Study No. & Cover Type & Mill/Mine Material & $\begin{array}{l}\text { Growth Medium } \\
\text { Thickness (cm) }\end{array}$ & $\begin{array}{l}\text { Root Egress } \\
\text { Studies }\end{array}$ \\
\hline SC-1-78 & Simple & Oxidized siliceous tailings & 15.0 to 120.0 & Yes \\
\hline SC-2-78 & $\begin{array}{l}\text { Complex } \\
\text { (30 cm float rock) }\end{array}$ & Oxidized iron tailings & $30.0,60.0,120.0$ & Yes \\
\hline SM-1-78 & Simple & Waste rock & $7.5,15.0,30.0$ & No \\
\hline SC-3-80 & $\begin{array}{l}\text { Complex } \\
\text { (float rock) }\end{array}$ & Oxidized iron tailings & 60.0 & Yes \\
\hline SC-1-89 & $\begin{array}{l}\text { Complex } \\
\text { (float rock) }\end{array}$ & Oxidized siliceous tailings & $30.0,60.0,90.0$ & Yes \\
\hline SC-2-89 & $\begin{array}{l}\text { Complex } \\
\text { (gypsum + Float } \\
\text { Rock) }\end{array}$ & Oxidized iron tailings & $45.0-60.0$ & No \\
\hline SC-3-89 & $\begin{array}{l}\text { Simple + complex } \\
\text { (float rock) }\end{array}$ & Gypsum tailings & $30.0,60.0-90.0$ & No \\
\hline SC-1-93 & $\begin{array}{l}\text { Complex } \\
\text { (gravels) }\end{array}$ & Calcine tailings & $30.0,60.0$ & No \\
\hline SC-2-93 & $\begin{array}{l}\text { Simple + complex } \\
\text { (float rock) }\end{array}$ & Gypsum tailings & $30.0,60.0$ & No \\
\hline SC-1-94 & $\begin{array}{l}\text { Simple + complex } \\
\text { (float rock) }\end{array}$ & Oxidized siliceous tailings & $\begin{array}{l}\text { Various combinations } \\
\text { of layers }\end{array}$ & Yes \\
\hline
\end{tabular}

\subsection{Soil cover studies, soil development, root egress and metals uptake in vegetation}

Vegetation establishment and growth response was relatively consistent throughout the various studies. In general, $30 \mathrm{~cm}$ of growth medium (glacial till) was required to obtain acceptable growth of grass dominated plant communities and $60 \mathrm{~cm}$ was required to promote an acceptable legume - grass plant community (Gardiner et al., 1983). Depths beyond $60 \mathrm{~cm}$ increased vegetative cover but changes in dry weight production were not significant (Przeczek and Halko 1995).

In 1995, 1996 and 2000 a number of complex cover experiments were examined for soil profile development, root development, translocation of metals through the constructed soil profile, and uptake of 
metals in vegetation. A backhoe was used to expose a trench through each configuration of a complex cover to a depth that exposed the contact with the underlying tailings.

Root systems occupied the available rooting volume in the reconstructed soil and penetrated into or through the underlying float rock capillary barrier. The depth of root penetration depended upon the age of the cover with the oldest covers having the most complete penetration. There were no cases where root systems were observed growing into tailings. Metals concentration (As, $\mathrm{Cd}, \mathrm{Pb}, \mathrm{Zn}$ ) in vegetation collected from the sample locations were generally within normal levels for vegetation growing on uncontaminated sites (Adriano 1986) and below the maximum tolerable dietary levels for domestic animals (NRC, NAS 1980).

Soil development was most pronounced at the oldest sites (16 and 19 years) and was expressed as darkening of the A horizon and changes in soil structure. Studies indicated that a float rock capillary barrier was effective in reducing the movement of acids, salts and metals into the growth medium which is consistent with investigations completed in the early 1980's (Gardiner et al, 1983).

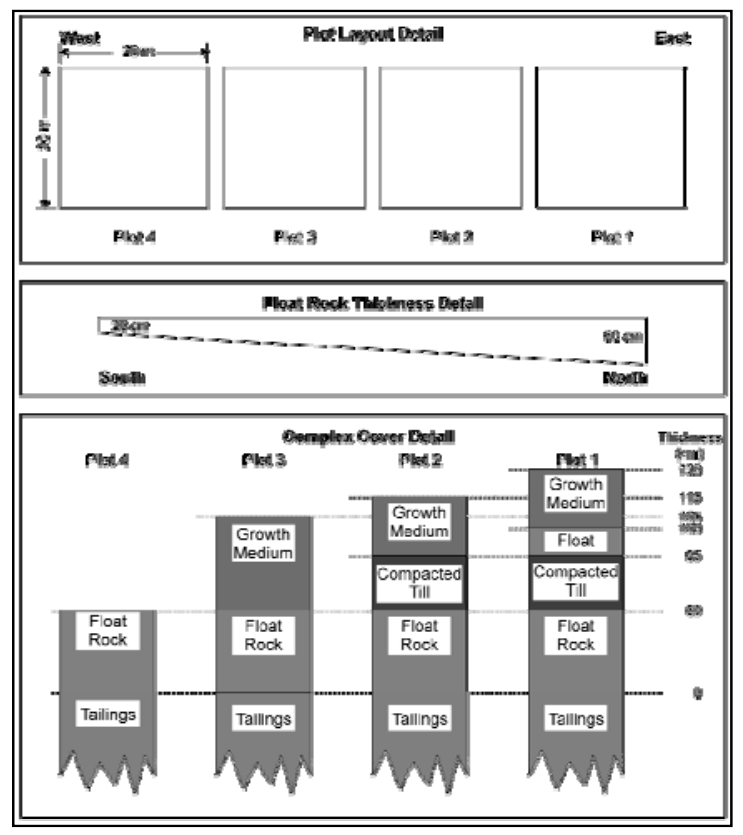

Figure 1 Treatment layout and complex cover details, research experiment SC-1-94 (from Przeczek and Halko, 1995, p. 79)

\subsection{Native tree and shrub species screening trials}

Meeting the end land use objectives required developing techniques that would promote the survival of a wide range of native tree and shrub species. This was a critical component of the revegetation program to ensure that a diversity of plant communities and habitats could be created.

Initial attempts to establish trees and shrubs focused on modifying mine and mill wastes with a variety of amendments including lime and fertilizer (Gardiner 1974). Seedling survival was highly variable and plantings were not successful. Through the mid 70's and 80's woody species were often planted at the time of seeding with various grass and legume seed mixes. Survival was generally poor and there was limited opportunity to determine which tree and shrub species had the greatest potential for use in the reclamation program (Przeczek, 2004). From 1991 to 1996 a series of species screening trials were established to determine the most effective approaches to promote seedling establishment and growth.

All attempts to plant into areas that were previously established with seeded grasses and legumes failed. Prepared planting sites were quickly reinvaded by the seeded grasses and legumes; moisture competition and mechanical damage were not controlled. The use of glacial till islands $(20 \times 20 \mathrm{~m})$ and corridors $(3 \times 100 \mathrm{~m})$ 
was tested in 1995. These features were $50 \mathrm{~cm}$ thick and they were not seeded with agronomic grasses and legumes. Przeczek and Erickson (2000) reported that seedling survival for many species was considered acceptable and that the most significant reasons for the improved seedling survival were:

1. Reduction of moisture competition from grasses and forbs.

2. Increased rooting volume associated with the islands and corridors.

3. Better seedling quality from participating nurseries.

4. Improved seedling handling procedures.

5. Use of local provenances.

This general design was incorporated in the closure plan for the Sullivan Mine which states that approximately $5 \%$ of the surface area of the tailings pond surface will be covered with planted islands and corridors to ensure that the wildlife end land use is realized and that habitat diversity is promoted.

\section{Operational treatments}

"The complex cover systems used at the Sullivan Mine have two main roles: to significantly reduce precipitation infiltration into potential ARD sources (e.g., tailings, waste dumps) and to act as a medium for the establishment and growth of herbaceous vegetation and native trees and shrubs.

The soil cover system is similar among locations although minor site-specific differences occur in either the float rock or glacial till depths. The soil cover system consists of a float rock capillary barrier, a compacted glacial till infiltration barrier and growth medium layer (Figure 2, Plot 2). The float rock capillary barrier is placed directly over either tailings or waste rock and ranges in thickness from 0.3 to 1.5 meters. Glacial till is placed over the float rock in a single layer approximately $0.5 \mathrm{~m}$ thick, which is compacted to $95 \%$ of maximum dry density during placement to form a layer with low permeability. The upper 0.20 to $0.25 \mathrm{~m}$ of the compacted till layer is subsequently scarified (ripped) to provide a growth medium with a bulk density suitable for vegetation establishment and normal root growth. Agronomic grass and legume dominated plant communities and native grass communities are established on the growth medium using a variety of seeding and fertilization techniques” (Przeczek 2011, p. 7).

The east gypsum pond was covered in 1995 and revegetation treatments began in 1996; the final borrow pit will be revegetated in 2012 .

\subsection{Operational approach}

\subsubsection{Soil cover placement}

Float rock was transported from the stock pile adjacent to the concentrator out to the tailings impoundment area and was spread with crawler tractors. A series of borrow pits were located adjacent to the tailings impoundments and industrial complex to minimize haul distances. Glacial till was transported with a combination of dump trucks and scrapers and crawler tractors were used for spreading. Compaction requirements were achieve through on-site traffic; specific compacting treatments were not required.

\subsubsection{Placement of corridors, islands and other habitat elements}

Islands and corridors, totalling approximately $5 \%$ of the surface area of a tailings impoundment area, were placed directly on top of the compacted glacial till prior to seeding and fertilisation treatments. Corridors were generally $3 \times 200 \mathrm{~m}$ long and islands were $20 \times 20 \mathrm{~m}$; both were a minimum of $50 \mathrm{~cm}$ thick. Additional habitat elements include standing dead trees (snags) and coarse woody debris piles were also placed at this time.

\subsubsection{Revegetation}

The operational revegetation program started in 1995 with the placement of the complex soil cover on the east gypsum pond. Approximately 1000 ha of mining related disturbances were reclaimed by the end of 
2010. We will be assessing all reclaimed areas in 2011 and remedial treatments will be prescribed where necessary.

\subsubsection{Grasses and legumes}

The initial ripping and seeding treatment at the east gypsum pond were completed in the fall of 2005 but subsequent investigations indicated that, due to the weakly to moderately calcareous (Expert Committee on Soil Survey, 1982) nature of the glacial tills in the area, a thin crust $(0.5-1.5 \mathrm{~cm})$ formed on the ripped material and the crust reduced germination success. Subsequent ripping treatments were completed in the spring of each year just prior to seeding operations.

Table 2 shows a typical seed mix that was used for the revegetation of the Sullivan Mine site. Seed was spread at a rate of $50 \mathrm{~kg} / \mathrm{ha}$ using a tractor pulling a heavy harrow. Tractors, rather than aerial seeding, were used to ensure that corridors and islands for tree and shrub planting would not be seeded. Fertiliser was applied using a tractor until there was a large enough area to justify applying by helicopter. Concerns with uneven fertiliser application, as evidenced by "banding", resulted in a shift back to the use of tractors. Maintenance fertiliser was applied for $3-7$ years depending on the site. Table 3 provides typical fertiliser formulations and application rates.

Table 2 Typical seed mix used for revegetation at the Sullivan mine, Kimberley, BC

\begin{tabular}{lll}
\hline Plant Species & $\begin{array}{c}\text { \% by } \\
\text { weight }\end{array}$ & $\begin{array}{c}\text { \% by } \\
\text { composition }\end{array}$ \\
\hline $\begin{array}{l}\text { Hard fescue } \\
\text { [Festuca trachyphylla (Hack.) Krajina] }\end{array}$ & 15 & 34 \\
$\begin{array}{l}\text { Crested wheatgrass } \\
\text { [Agropyron cristatum (L.) Gaertn.] }\end{array}$ & 15 & 12 \\
$\begin{array}{l}\text { Alfalfa } \\
\text { [Medicago sativa L.] }\end{array}$ & 35 & 34 \\
$\begin{array}{l}\text { Slender wheatgrass } \\
\text { [Elymus trachycaulus (Link) Gould ex Shinners ssp. trachycaulus] }\end{array}$ & 15 & 11 \\
$\begin{array}{l}\text { Pubescent wheatgrass } \\
\text { [Agropyron trichophorum fo. barbulatum (Schur) Anghel \& } \\
\text { Morariu }\end{array}$ & 20 & 9 \\
\hline
\end{tabular}

Table 3 Typical fertiliser formulations and application rates for revegetation at the Sullivan mine, Kimberley, BC

\begin{tabular}{lll}
\hline Purpose & Formulation & Application Rate (kg/ha) \\
\hline Establishment & $11-52-0$ & 400 \\
Establishment & $8-25-18-4-0.6 \mathrm{~B}$ & 400 \\
Maintenance & $46-0-0$ & 110 \\
Maintenance & $19-14-14-4-0.5 \mathrm{~B}$ & $90,175,235$ \\
\hline
\end{tabular}

In 1999 the desire to incorporate additional levels of biological diversity into the revegetation program lead to a decision to seed native grasses on the islands and corridors planted with native trees and shrubs. Table 4 shows a typical native grass seed mix. Moisture competition from seeded native grasses in combination with severe growing season drought in 2003 caused wide spread mortality of planted trees and shrubs. This 
resulted in restructuring of the revegetation program. Specific locations within each tailings pond area were seeded with native grass species and islands and corridors were no longer seeded.

Table 4 Typical native seed mix for revegetation at the Sullivan mine, Kimberley, BC

\begin{tabular}{lll}
\hline Plant Species & $\begin{array}{l}\text { \% by } \\
\text { weight }\end{array}$ & $\begin{array}{l}\text { \% by } \\
\text { composition }\end{array}$ \\
\hline $\begin{array}{l}\text { Bluebunch wheatgrass } \\
\text { [Pseudoroegneria spicata (Pursh) A. Löve ssp. spicata] }\end{array}$ & 42 & 25 \\
$\begin{array}{l}\text { Rough fescue } \\
\text { [Festuca campestris Rydb.] }\end{array}$ & 35 & 30 \\
$\begin{array}{l}\text { Idaho fescue } \\
\text { [Festuca idahoensis Elmer] }\end{array}$ & 13 & 25 \\
$\begin{array}{l}\text { Rocky mountain fescue } \\
\text { [Festuca saximontana Rydb.] } \\
\begin{array}{l}\text { Sandberg bluegrass } \\
\text { [Poa secunda J. Presl] }\end{array}\end{array}$ & 6 & 5 \\
\hline
\end{tabular}

\subsubsection{Native trees and shrubs}

A needs analysis was conducted to determine the amount of seed that would be required for each tree and shrub species used in the revegetation program. Surplus conifer seed was purchased from the Ministry of Forests to ensure that closure requirements would be met. Aspen, cottonwood and willow seeds were collected annually to meet project requirements for the following year and other species were collected to maintain a two year supply to buffer against poor seed crop years. All seed collections (except wolfwillow) were conducted within $20 \mathrm{~km}$ of the mine site.

All seedlings were planted in the spring. Tailings pond sites were planted in mid - late April and planting at the upper mine site was completed in mid - late May. The till in the islands and corridors was ripped in the fall of the year before planting because melted snow that accumulates over the winter provides increased moisture for seedling survival and relatively easy penetration of planting shovels. Seedlings were produced by various nurseries as 1 year old frozen stored container stock with a rooting volume of $39-60$ cc (PSB $1+0$ 313A, 410A, 412A, and 415B). All seedlings were planted by local forestry planting contractors and a $10 \mathrm{~g}$ fertilizer tea bag (Reforestation Technologies International, Bio Pak 16-6-8 plus minors and biostimulants) was planted with each seedling to promote improved survival and growth. Table 5 provides the list of species that were used in the planting program from $1996-2007$.

\subsection{Results of the revegetation program}

\subsubsection{Seeded grasses and legumes}

Revegetation efforts at the Sullivan Mine have produced agronomic grass and legume plant communities that typically have annual total dry weight biomass production that ranges from $1000-2500 \mathrm{~kg} / \mathrm{ha}$. This compares favourably with a native range site that is also monitored regularly (Figure 2). Annual total dry weight biomass production of seeded native grasses has ranged from $700-2100 \mathrm{~kg} / \mathrm{ha}$ on various sites from 2005 - 2010. A cryptobiotic crust, which is one measure of grassland health (Adams et al., 2003, p. 27) starts to form on the reconstructed soils within four years of placement and the distribution of the crust expands over time. Areas seeded native grasses tend to be less than 0.3 ha in size and they are being encroached by the adjacent agronomic plant communities.

Expanding ungulate populations are preferentially grazing fescue species and this may reduce the fescue component of the plant communities over time. Ungulates have also been identified as being directly responsible for disturbing the establishing cryptobiotic crusts in some areas. Burrowing rodents at the native range site have also been identified as agents of soil disturbance. Increased levels of soil disturbance provide 
seedbeds for noxious weeds, we have seen spotted knapweed (Centaurea maculosa Lam.) establish on the native range site in the past 5 years, and may influence biogeochemical cycling in the reconstructed soils.

Table 5 Native tree and shrub species used for revegetation at the Sullivan Mine, Kimberley, BC

\begin{tabular}{ll}
\hline Common name & Latin name \\
\hline lodgepole pine & Pinus contorta Douglas ex Louden var. latifolia Engelm. ex S. \\
& Watson \\
ponderosa pine & Pinus ponderosa C. Lawson \\
hybrid spruce (Engelmann x white) & Picea engelmannii Parry ex Engelm. x glauca (Moench) Voss \\
western larch & Larix occidentalis Nutt. \\
black cottonwood & Populus balsamifera L. ssp. trichocarpa (Torr. \& A. Gray ex Hook.) \\
trembling aspen & Brayshaw \\
upland willow (2 species) & Populus tremuloides Michx. \\
wolfwillow, silverberry & Salix spp. \\
prickly rose & Elaeagnus commutata Bernh. ex Rydb. \\
chokecherry & Rosa acicularis Lindl. \\
Saskatoon, service berry & Prunus virginiana L. \\
bitterbrush, antelope brush & Amelanchier alnifolia (Nutt.) Nutt. ex M. Roem. \\
shrubby cinquefoil & Purshia tridentata (Pursh) DC. \\
snowbrush & Dasiphora fruticosa ssp.. floribunda (Pursh) Kartesz \\
Douglas maple & Ceanothus velutinus Douglas ex Hook. \\
\hline
\end{tabular}

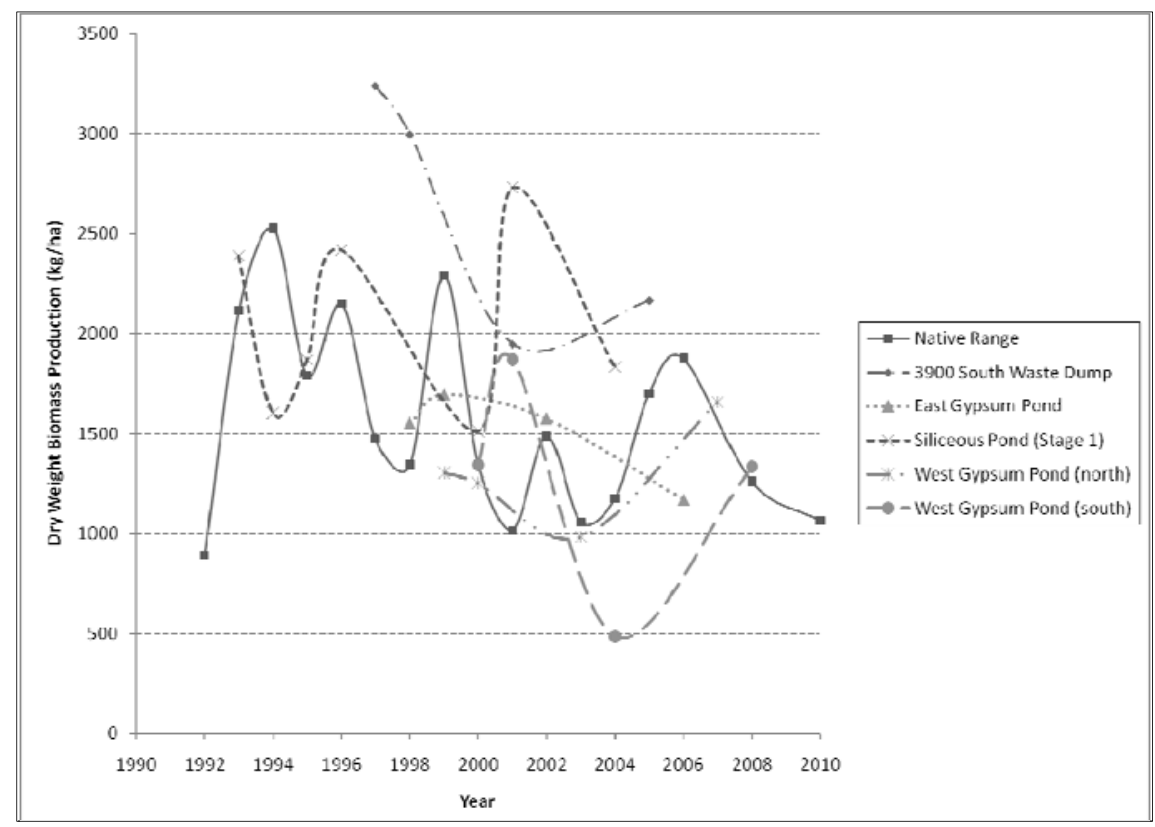

Figure 2 Total annual dry weight biomass production (kg/ha) from selected sites, $1992-2010$, Sullivan Mine, Kimberley, BC 


\subsubsection{Tree and shrub seedling survival}

The species listed in Table 5 were used consistently throughout the planting program. Figure 3 presents results from formal survival plots established on islands that were seeded with native grasses. In 2004 the survival had dropped to less than 5\% for all species. Figure 4 presents results from survival monitoring plots that were not seeded with native grasses and survival of most species continues to be acceptable four years after planting.

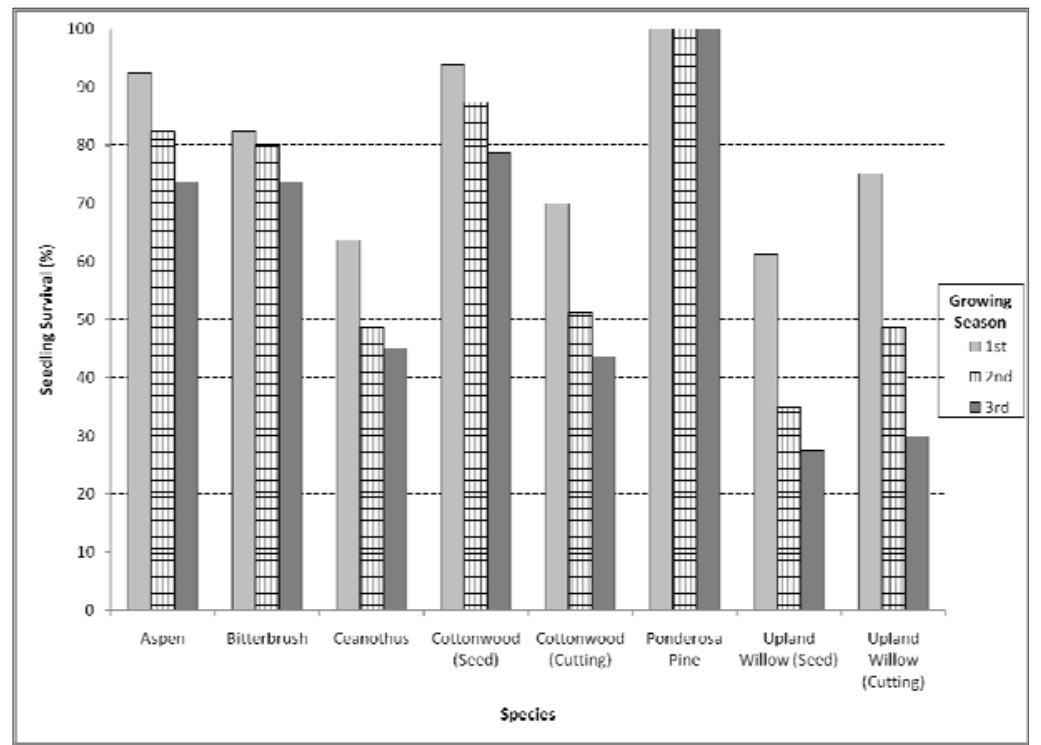

Figure 3 Native tree and shrub survival over 3 growing seasons on the Siliceous Pond Stage 2, 2000 2002 (after Przeczek and Erickson, 2003, p. 34)

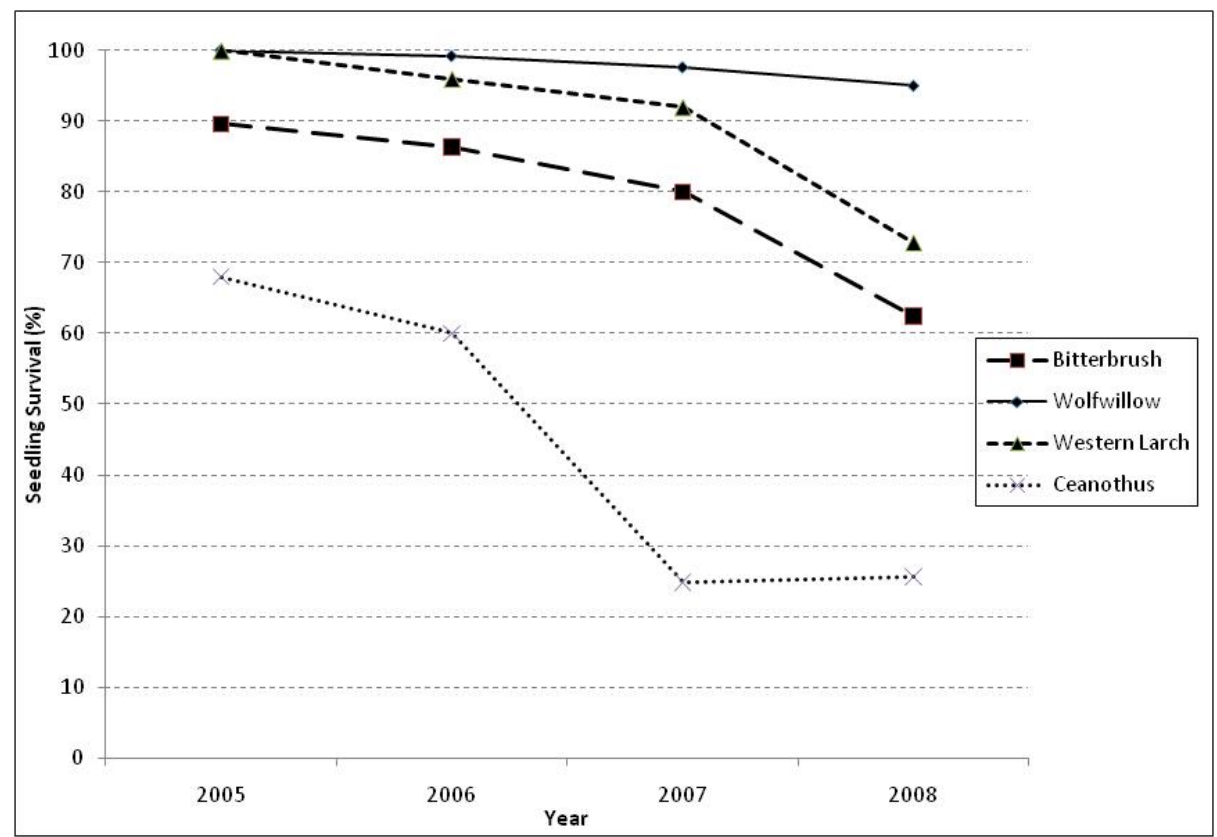

Figure 4 Survival of selected native tree and shrub species over 4 growing seasons on the Active Iron Pond, 2005 - 2008. 
Survival data alone does not provide sufficient information to determine if the tree and shrub planting program have been successful. All deciduous tree and shrub species planted since 2005 have been heavily hedged by deer and elk. They provide good browsing opportunities but they will not provide the vertical and horizontal structure, screening cover or nesting habitat elements that they were designed to provide . Western larch and ponderosa pine will provide some vertical diversity but they will not provide the shrubby thickets that are desirable for passerine bird nesting habitat.

\subsubsection{Other habitat elements}

Standing dead trees (snags) and coarse woody debris piles are being used by raptors and other bird species as perching habitat.

\subsection{General observations}

There has been a noticeable increase in the diversity of vertebrate species and number of individuals of each species that are using the reclaimed mine site. Elk herds in excess of 200 animals are common and they are obviously fecund as the herds continue to grow. Mule deer are found in smaller numbers; they are also productive and there has been an obvious increase in population size. Rough-legged hawks appeared on the site approximately four years ago and there is an increasing population of coyotes. We have seen evidence of an increasing rodent population at the native range site and the increasing predator population is a good indicator that the rodent population is increasing throughout the property.

The most obvious change at the site has been the reintroduction of passerine bird species. We have noted evidence of successful nesting on the site and whenever you walk through a portion of the reclaimed area you notice the diversity of bird songs around you. In 1992 it was unusual to notice any bird activity.

\section{$4 \quad$ Significant lessons}

\subsection{Get the biology right, focus on limiting factors}

You need to develop a clear understanding of the biological factors that have the potential to limit reclamation program success. Growing season moisture deficit was identified as the major limiting factor at the Sullivan Mine and we designed our treatments and operational activities to reduce the impacts of drought. This included designing drought resistant seed mixes, reducing vegetation competition where trees and shrubs were planted, appropriate species selection, planting as early as possible after snow melt, rigorous stock handling procedures to minimize seedling stress, and setting up snow caches to control seedling temperatures. However, we did not forecast the large increase in ungulate populations and their impact on the revegetation program.

\subsection{Know where you are going, revisit and revise objectives as new information becomes available}

It is difficult to know if you are being successful without a set of clearly defined and measureable objectives or standards. Each mine site is unique and we believe that it is important to spend time to set a definite direction for the revegetation program through a well considered results-based reclamation plan. A well designed set of results-based reclamation objectives and standards provides the framework and sets the course for effective reclamation treatments over the long term. The plan may require revision as new information becomes available and you may have to revisit the specific measures that are used to define success.

\subsection{Create effectively sized habitats}

If you are trying to create specific habitat types you need to make sure that they are large enough to make a difference to the wildlife species that you are targeting. The islands we created $(20 \times 20 \mathrm{~m})$ are probably the minimum size that should be considered. Three meter wide corridors are too narrow; they provide some important habitat elements but there is too much influence from the adjacent grass/legume plant communities. They would have been more effective if they were 12 or 16 meters wide and fewer had been 
constructed to meet the 5\% target area set in the closure plan. Also, small habitat inclusions are invaded more quickly by species from adjacent habitats; they need to be large enough to minimize these impacts.

\subsection{Design and implement monitoring programs that feed adaptive management decision making}

Significant questions required careful consideration during the development and implementation of the reclamation program at the Sullivan Mine. As questions were identified studies were implemented to help answer them. These studies were conducted well in advance of the implementation of the closure plan and Teck Metals Ltd. was then prepared to proceed with good empirical results to provide guidance. All treatments were monitored throughout the implementation of the closure plan and we have used some of the information to make changes to our practices as we moved along. Monitoring will continue to ensure that reclamation objectives are being achieved and the monitoring program will continue to evolve as additional questions are identified.

\subsection{Maintain an enduring curiosity and a sense of humour; be humble}

Whenever you are tinkering with biological systems, particularly on severely disturbed sites, you should expect some failures; build this into your risk management strategy. It is important to recognize that biological cycles exist and it is the extremes that control our ability to be successful; average conditions are difficult to find. Three to seven years of good growing season moisture distribution may be followed by one to three years of severe growing season moisture deficits. The droughty period may result in unacceptable mortality which requires replanting; do not let these difficult periods in the cycle cause knee-jerk reactions that result in unnecessary costs or move you away from treatment combinations that are successful in the better parts of the cycle.

\section{Acknowledgements}

Successfully achieving this major undertaking was possible, in part, because of over 27 years of active reclamation research. Mr. Bob Gardiner (deceased) was directly responsible for the vision, depth, and rigour of the research at the Sullivan Mine and much of the credit for our success lies with him.

\section{References}

Adams, B. W., G. Ehlert, C. Stone, M. Alexander, D. Lawrence, M. Willoughby, D. Moisey, C. Hincz, and A. Bogen (2003) Range health assessment for grassland, forest and tame pasture, Public Lands Division, Alberta Sustainable Resource Development, Pub. No. T/044, 105 p.

Adriano, D.C. (1986) Trace elements in the terrestrial environment, Springer-Verlag, New York, 533p.

Expert Committee on Soil Survey (1982) The Canada soil information system (CanSIS): manual for describing soils in the field, 1982 Revised, Land Resource Research Institute, Research Branch, Agriculture Canada, Ottawa. LRRI Contribution no 82-52, 166 p.

Gardiner, R.T. (1974) Mined-land reclamation at Cominco Ltd., Sullivan Operations: progress report 1974, Cominco Ltd. Kimberley, BC., 21p + appendices.

Gardiner, R.T. and D.K. Rusnell (1980) Sullivan Mine and concentrator annual reclamation report and proposed program for 1980, Cominco Ltd. Unpublished Report, 13 p. + appendices.

Gardiner, R.T., A.L. Burrows, and D.K. Rusnell (1983) Sullivan Mine and concentrator annual reclamation report for 1982. Cominco Ltd. Unpublished Report, 20 pp + appendices.

NRC, NAS (1980) Mineral tolerance of domestic animals, National Academy Press, Washington, DC, 577 p.

Przeczek, John and Robert Halko (1995) 1994 reclamation research report. Cominco Ltd., Kimberley Operations. Unpublished Report. 100 pp + appendices.

Przeczek, John and Doug Erickson (2000) 1999 reclamation research report, Cominco Ltd., Kimberley Operations. Unpublished Report. 49 p + appendices.

Przeczek, John and Doug Erickson (2003) 2002 operational vegetation establishment and monitoring report, Teck Cominco Metals Ltd., Kimberley Operations, Unpublished Report, 48 p + appendices.

Przeczek, John (2004) A review of the reclamation research program at Teck Cominco’s Sullivan Mine at Kimberley, BC, Proceedings of the 2004 BC Mine Reclamation Symposium, BC Technical and Research Committee on Reclamation, June 23-24, Cranbrook, BC, Canada, 7 p.

Przeczek, John (2011) 2010 operational vegetation establishment and monitoring report, Teck Metals Ltd., Kimberley Operations, Unpublished Report, 32 p + appendices. 